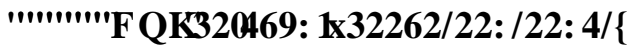

\title{
SAFETY OF FLYING IN THE AIR IN ASPECT OF USING ELECTRONIC WARFARE DEVICE
}

\section{BEZPIECZEŃSTWO WYKONYWANIA LOTÓW W PRZESTRZENI POWIETRZNEJ W ASPEKCIE ZASTOSOWANIA URZĄDZEŃ WALKI ELEKTRONICZNEJ}

\author{
Mariusz Masiewicz, Leszek Loroch \\ Air Force Institute of Technology \\ Instytut Techniczny Wojsk Lotniczych \\ 01-494 Warszawa, ul. Księcia Bolesława 6 \\ e-mail: mariusz.masiewicz@itwl.pl, leszek.loroch@itwl.pl
}

\begin{abstract}
The paper presents some problems of the safety of military air forces in the area of enemy air defence. Recently, this problem has become one of the most important issues of fighting against terrorists. Presented are some threats and techniques of fighting them. On the grounds of the threats analysis in the air defence areas, the author tries to predict safety condition in function of the quality and effectiveness of an onboard electronic warfare system.
\end{abstract}

Keywords: electronic warfare, countermeasures, database, aircraft, and defence system.

Summary: This paper presents some problems concerning safe realisation of missions by air forces within a zone of the enemy antiaircraft defence. Over recent years this problem has become one of key issues of fighting against threats of terrorism. The paper presents threats and techniques of fighting them. Based upon the analysis of threats over areas where dense fire air defence are located, the author makes an attempt to predict safe conditions as a function of the quality and effectiveness of the on-board electronic warfare defence system.

Słowa kluczowe: walka elektroniczna, przeciwdziałanie, baza danych, statek powietrzny, system osłony 


\section{SAFETY OF FLYING IN THE AIR IN ASPECT OF USING ELECTRONIC WARFARE DEVICE}

\section{Introduction}

Flight safety as seen from the aspect of the application of electronic warfare systems determines the degree of adaptation/capability of an aviation system to ensure health and life of all the fight participants, and to preserve an aircraft, coexisting objects and the environment when carrying out a flight mission. Every detected and ID-ied threat should be neutralised automatically or, as an option, manually by a threat counteracting system. Therefore, every specific threat must trigger a defined response from a counteracting system e.g. a flare launch pad or a dipole system - i.e. a determined sequence of interferences - should be launched to mislead/confuse as much as possible a radar system or a warhead of a guided infrared missile.

\subsection{Aircraft safety factors as a function of electromagnetic threat}

Most aircraft individual defence systems ensure a relative mission safety over areas of a low density of enemy radio electronic means.

In these circumstances, the factor of a safe mission will be a reliable database of threats correlated with an effective system of counteracting detected threats. The credibility of a database is determined based on the selection of an appropriate number of standards of electromagnetic radiation for a chosen area of application, the parameter quality of these standards and the effectiveness of the target bearing taking process. Another factor affecting the mission safety level is the effectiveness of the response of the threat counteracting system.

In order to present the problem of ensuring the aircraft safety when flying over zones of high risks, one ought first of all to discuss threats and then to determine possible options of counteracting these threats.

Basic elements increasing the safety and invulnerability of an aircraft during a mission can be grouped into three basic categories: 1) evasion of detection, 2) evasion of being hit, and 3) survival after a hit. 


\section{Safety systems of contemporary aircrafts}

The aircraft individual defence system plays a key role for the aircraft safety whilst flying a mission. The main task of an aircraft individual defence system is to detect radiation as emitted by radars (on-board or these of antiaircraft rocket or flak systems) and by laser aiming systems. An important element of the defence is the detection and identification of launched rocket missiles and as well as developing and applying effective counteracting measures, e.g. such as using active and passive interfering devices and carrying out defensive manoeuvres. An on-board radio electronic warfare system comprises devices ensuring direct radio electronic protection and defence of aircraft, enabling relatively safe conducting its combat missions. Here, the following devices are distinguished:

a) warning and identificating receivers including:

- radar warning receivers;

- laser warning receivers;

- missile warning systems;

b) active radar jamming systems;

c) stations/transmitters for radio electronic disturbance and infrared misguiding devices;

- IRCM (Infrared Countermeasures) - acting around an aircraft in all directions;

- DIRCM (Directed IRCM) - emitting directionally;

d) active infrared interference systems: towed trap-decoys;

e) passive infrared disturbance systems (flares) and systems operating within radiolocation operation ranges (chaff-dipoles).

\subsection{Threats for aircrafts}

However, aircraft armament manufacturers follow aircraft defence design development. Operation parameters of opto-electronic devices (TV, laser, thermo vision and combined systems) available on the world weapons market are close to those of close range radiolocation transmitters. So far, the main signal source for a missile warhead was waste gas and engine parts (distinguishable in a thermal spectrum). Nowadays, even devices dissipating a thermal trace (by cooling waste gases) can be distinguished. Moreover, the 9/11 tragic events in the USA proved not only air force craft must be specially protected. The analysis of threats to the safety of aviation traffic, both in military and civil aviation, show that first of all MANPAD class handheld antiaircraft sets must be considered. According to reports by the 
CIA, since 1970 at least 29 cases of attacks against civil aviation aircraft with portable MANPAD devices were recorded. 30 planes were shot down as a result of which over 700 people lost their lifes. It was established that from the total number of 700,000 of worldwide manufactured MANPAD sets some undefined number of these pads are at terrorist disposal. Currently, rocket missiles are provided with high-class thermo-scanners which, when analysing a spectrum and comparing data gained from measurements against a database, are capable of easily evading thermal traps. In addition, most recent rocket systems are capable of ,seeing" more than one spectrum range. Apart from the infrared analysis of a spectrum, a missile warhead analyses a spectrum in a so-called closed ultraviolet range NUV. Within the close ultraviolet range, light disperses perfectly in the atmosphere. When a stable object (an aircraft, a helicopter) appears in the air, strong absorption of a radiation by an object follows and it becomes well seen (a dark spot) when using a NUV warhead.

\subsection{Threat detection techniques}

All the users of the air space fully agree that the only efficient measure of counteracting a threat by MANPADs is to install on an aircraft airframe sensors warning against a launched and oncoming rocket missile (a Missile Warning System class), and rotating laser heads affecting directionally the infrared sensor in the warhead of the launched missile.

The job of an MWS device is to detect and determine the kind of threat (the type of missile). Detection of a thermal spectrum generated within the space of an operating rocket engine and determination of its class based on the data in the data library, and determination of the rocket direction and approach speed allows for alerting the crew on a pending threat with it being simultaneously identified. An on-board self-protection management system should be capable of automatically classifying the threats and "suggesting" a procedure of fighting dangers (automatically or manually). The MWS system can utilise a technique of a passive detection (optical head) or active detection (the so-called ,quiet radar"). The passive system has an advantage of a better detection time (longer interval between threat detection and missile hit). This system provides information on a pending threat as soon as a missile is launched from an enemy aircraft.

Its disadvantage is the lack of detection a rocket in the event in which the fuel combustion temperature within the missile engine is outside the detector operating range. In case of using active detection, any point of the projectile trajectory can be detected. This is possible due to the 
measurement of the effective reflection surface - RCS (Radar Cross Section) of a missile.

Another advantage is that the time remaining till the missile hits can be counted, thus aircraft own defence system (e.g. thermal traps) can be properly deployed. However, the MWS active detection systems drawback is the short warning time; in addition, the missile can be within the so-called velocity gate, thus the missile trajectory cannot be tracked. Also, if the „stealth" technology (RCS reduction) is used, the receiver detection capability is significantly reduced. The early detection capability combined with the enhanced capability of the angle UV and infrared tracking provides the aircraft own system with the ability to effectively detect DIRCM class devices, which combined with a dodging manoeuvre should provide sufficient protection and defence.

The Radar Warning System is a basic element of the radio-electronic defence system of the aircraft. Presently, a third generation of receivers digital receivers (operating with e.g. RISC processors) - is used. These receivers must cope with more and more refined tracking technology. Due to the application of radars of increasingly wider searching spectrum ranges, a $0.5 \div 40 \mathrm{GHz}$ - prospectively even up $0.1 \div 94 \mathrm{GHz}$ - frequency range detection band must be used. As PD - pulse-Doppler - radars operate with constant frequency pulse sequences, sufficient precision could be achieved even with a $10 \mathrm{MHZ}$ distribution. However, the assumed scenarios take into account several or a dozen or so PD radars being operated, and then it turns out that pulse shifts within the examined signal spectrum can be insignificant. Therefore, the assumption that two pulses do not occur at frequencies closer to each other than $10 \mathrm{MHZ}$ will not be true. It is desirable to achieve $1 \mathrm{MHZ}$ sampling frequency. From the $\mathrm{K}$ band $(20-40 \mathrm{GHz})$ and above, such a resolution would be useful only for short range detection, and enhancing this option above $40 \mathrm{GHz}$ would be useful only for missiles actively homed onto a target. Identical reasoning is adopted for detection of a continuous wave character signal. With the frequency analysis, the RWR can filter frequencies, identify threats and order them. For an effective disturbance of a radar operating with a continuous wave, the width of an interfering signal must be very low, therefore the range of measuring intervals between pauses should be from $25,000 \mu$ s to $0,5 \mu \mathrm{s}$. Theoretically, it is therefore possible to track and locate a device at a distance of up to $3,750 \mathrm{~km}$. Measuring the amplitude makes it possible to measure the distance to the radiation source. Determination of a range by analysing the amplitude is a method of a rough estimation (often burdened with an error up to $50 \%$ ). This is due to the fact the transmitter power can be adjusted. 
However, what is important is that the RWR receiver is capable of distinguishing the amplitude of a signal source in order to use an appropriate dose of the interfering signal. The precision of an angular bearing/location should be of $1^{\circ}$ (the average value) but when a plane carries out complicated manoeuvres, the precision can be down even by $10^{\circ}$. The angular range of observation shall amount to $360^{\circ}$, in the azimuth and $\pm 60^{\circ}$ at elevation (in order to minimise craft manoeuvring affecting the receiving capability of a device, a wider range of is desirable). The library capacity should be at least 1,500 different kinds of transmitters (radiation sources). Another kind of device which to certain extent is similar to that of the RWR and responsible for the aircraft safety is the laser radiation detector (Laser Warning Receiver - LWR) designed to detect, process and visualise threats related to the illumination of an aircraft by an alien laser system, rangefinder or a laser target illuminator. The operation range of a device must ensure a sufficiently fast response to a threat, i.e. such a device must quickly enough take decisions on using aircraft own defence system.

\subsection{Threat counteracting technology}

Depending on the quality of a detection process, a defined level of the system reaction is available; the better a threat is identified, the more efficient a counteracting measure can be. Counteracting measures (interfering devices) are generally divided into the following groups:

- OBRCM systems (On-board Radar Countermeasures);

- OBIRCM sub-systems (On-board Infrared Countermeasures subsystems);

- OBCM (Out-board Radar Countermeasure);

- out-board infrared interfering systems OBIRCM systems (Out-board

Infrared Countermeasures systems);

- Laser Countermeasures sub-systems.

The OBRCM active disturbance is realised by emitting signals interfering within an alien SRL operating frequency. The simplest kind of interference is a noise disturbance. Within determined frequencies or within their bands, sustained noises are generated which then block a certain range of frequency, thus making it impossible for a device to operate within it. Interference of this kind can be generated effectively by large and heavy transmitters, which can be carried only by adequately large planes. The most effective type of active disturbances are the so-called "confusing" disturbances, which utilise the signal retranslation technology. The effect of such an action is the generation of a false echo of an object, a false indication of a distance, azimuth and target elevation measuring system, 
therefore a disruption of the object tracking system process. Knowing the radar type and its characteristics in a system data library, we can without difficulty emit - whilst being illuminated with a side leaf - signal of an appropriately selected amplitude level. The signal received from a side leaf direction is treated by an amplitude discriminator as a real target and visualised on a monitor/indicator as a real target, which in reality does not exist. For most applications, the power of the emitted signal should be of about $1 \mathrm{~kW}$, yet it should be adjusted so that the emitted signal is directly bound with the reflection surface - RCS - (effective reflection surface). Devices of this kind must be capable of operating interference programmes against pulse radars, pulse and Doppler radars and radars operating with a continuous wave.

Towed decoys cover a frequency range of $4,5 \div 18 \mathrm{GHz}$. The system is controlled over a light pipe integrated with a cable (length 50 to $150 \mathrm{~m}$ ), which after launching the system connects it with the aircraft. The task of such a decoy is to generate a return signal (a signal imitating a radar reflection) with the amplitude adequately large so as to draw attention of enemy radiolocation guided enemy fire. These decoys are very difficult to locate and discriminate against a real target.

Such a decoy moves as fast and as high and in the direction of a real target, therefore algorithms for discriminating real targets against the background of interference (fake targets) based on speed tracking and angular position become very ineffective. A rocket missile warhead will attack a target of a greater radiolocation contrast, i.e. a decoy. In the opinion of American experts, it is just radiolocation towed decoys that are the most effective as measures protecting own strike forces. With their capacities, they are far ahead of all the other passive defence systems (radiolocation dipoles). The last type in this class is radiolocation dipoles launched from on-board launching pads similarly to thermal flares. This solution is underlined by the theory of dipole aerial, the outlet port of which is a short-circuited one. It has been established that electromagnetic waves are best effective in terms of reflections with dipoles of a length of a $0.46 \div 0.48$ wave length. The number of elementary radiolocation dipoles is a mathematical combination, which should generate a radiolocation cloud (of a defined RCS) in a space surrounding a defended aircraft. Such a cloud most effectively absorbs electromagnetic radiation within a set frequency band provided distances between dipoles are a multiple of two wavelengths.

To protect an object radio-electronically, charges containing dipoles of various lengths should be used so they cover the entire frequency range of $0.5 \div 18 \mathrm{GHz}$. 
This kind of protection is unfortunately ineffective with pulse - Doppler radars where a frequency difference between the signal sent and the one reflected from a moving target is measured. Metallized foil strips or metallized glass fibres move only with the wind falling continuously on the ground. With the Doppler effect, one can filter away signals from which this frequency difference is generated and fake targets generated by these dipole will disappear from the radio locator monitor. On-board IRCM (Infrared Countermeasure) sub-systems are interference devices which emit modulated energy (electromagnetic rays modulated with a pulse code) within a selected infrared range. This modulated energy (light pulses) cause a guiding and controlling section to err and results in an infrared guided missile being overtargetted.

Thermal flares are still the simplest and cheapest measure of infrared interference. However, they are less and less effective on a modern battlefield as it was especially experienced by the Soviet Union combat aircraft during the Afghanistan war. The basic function of a flare is to generate a source of thermal radiation of energy higher than that of a protected object. Most common are still pyrotechnical flares.

Currently used flares fired from an aircraft immediately after shooting them ensure energy commensurable with the engine radiation and with decreasing speed (of falling) this energy increases even 3 to 4-fold. The effectiveness of a thermal radiation protection cloud depends on the cooperation of the flare firing system with the threat detecting systems. The main problems are to select a proper moment to fire a flare (very short combustion time), the number of flares and the firing sequence. An aircraft pilot, whilst performing a manoeuvre according to the rules of air combat, can select the right moment to fire flares only in an accidental way. An important requirement for a flare is the time of initiation its combustion after it has been fired. It is essential for this initiation to start before a flare enters the vision field of a missile warhead. The problem of classic solutions remains the fact of a quick falling of a flare. It is assumed that in modern solutions flares shall also follow a protected object thus enhancing its effectiveness, as well as that the flash signature will match the thermal signature of the protected craft.

The main task of a LCMS subsystem (Laser Countermeasures Sub-system) is to increase the distance measuring error (overtargetting errors) by enemy rocket missile, which should lead to rocket explosion at a safe distance.

Detection and identification of threats related to the application of laser technology is realised by a LWN device in association with other warning sensors. Gravest problems are posed by counteracting laser range finders as 
they operate on very short light illuminating pulses and extremely short intervals between pulses. The most efficient way to fight threats of this kind is to emit a series of pulses of an appropriate amplitude level toward a range finder head in order to imitate a presence of at least several targets at larger distances. Modern systems are capable of sending signals at a distance of 150 sea miles.

\section{Summary}

The effectiveness of the algorithm (software) for the application of counteracting measures is evaluated under laboratory electronic warfare conditions - EW - (modelling) or at military rocket ranges. The effectiveness of counteracting hardware is determined depending on an adopted task programme at the stage of mission planning and forecast electromagnetic threats (EW scenarios). Programmes containing operational logarithms for aircraft protection devices are designed individually in every NATO member state and, similarly to the National Emitters Database, are protected as a state secret. Presently, the NATO has no appropriate measures available to protect civil aviation aircraft. However, NATO technical teams working on the protection of combat wide body aircraft deal with aspects which can be of interest to the owners of civil aviation aircraft. Studies and tests are being conducted to demonstrate the effectiveness of new infrared guiding systems counteracting technologies. Current regulations on operation of civil aviation under peace conditions prohibit using flares during operations on civil airfields and nearby. These regulations are in force even at imminent threats from terrorist groups also in case of crisis situations. Therefore, an option to protect civil aviation will be to establish the so-called microwave umbrella within a zone around an airfield, i.e. where the threat from MANPADS is most severe. Due to the new threat, which has become more intense over recent years (antiterrorist coalition operations in Iraq), there is a need to protect helicopter missions. The number of helicopters lost by the US Air Force due to hits by missiles from rocket launchers prompted the air forces to define a new operational need. This problem lays a new direction for developing measures to increase the safety of flight over enemy territory.

\section{Bibliography}

1. M. Masiewicz - Sprawozdania z pracy z lat 1999-2007r, w zespołach roboczych grupy uzbrojenia lotniczego NAFAG - ACG-3 oraz AHWG SIGINT/ESM Reports on studies conducted between 1999 and 2007 by Combat Aircraft Armament Working Teams - NAFAG - ACG-3 and AHWG SIGINT/ESM 


\section{BEZPIECZEŃSTWO WYKONYWANIA LOTÓW W PRZESTRZENI POWIETRZNEJ W ASPEKCIE ZASTOSOWANIA URZĄDZEŃ WALKI ELEKTRONICZNEJ}

\section{Wstęp}

Bezpieczeństwo lotów w aspekcie zastosowania systemów walki elektronicznej określa stopień przystosowania systemu lotniczego do zapewnienia zdrowia i życia wszystkich uczestników lotu, zachowania statku powietrznego, obiektów współistniejących i środowiska podczas wykonywania zadania lotniczego. Każde wykryte i zidentyfikowane zagrożenie powinno być neutralizowane w sposób automatyczny lub opcjonalnie ręczny przez system przeciwdziałania zagrożeniom. Wynika stąd, że na określony typ zagrożenia musi być wyzwolona określona reakcja ze strony systemu przeciwdziałania, np. z wyrzutni flar i dipoli powinna być wystrzelona właściwa sekwencja zakłóceń gwarantująca w największym stopniu zmylenie radaru bądź głowicy pocisku kierowanego na podczerwień.

\subsection{Wskaźniki bezpieczeństwa statku powietrznego w funkcji zagrożenia elektromagnetycznego}

Większość systemów osłony indywidualnej statków powietrznych zapewnia względne bezpieczeństwo wykonywania zadań na obszarach o małej gęstości środków radioelektronicznych przeciwnika. Funkcję wskaźnika bezpieczeństwa realizacji zadania lotniczego pełnić będzie $w$ tych okolicznościach wiarygodna baza danych zagrożeń skorelowana $\mathrm{z}$ efektywnym programem przeciwdziałania wykrytym zagrożeniom. Wiarygodność bazy danych ustala się na podstawie doboru odpowiedniej liczby wzorców źródeł promieniowania elektromagnetycznego dla wybranego obszaru zastosowania, jakości parametrów tych wzorców oraz skuteczności realizacji procesu namierzania. Kolejnym czynnikiem mającym wpływ na poziom bezpieczeństwa zadania jest efektywność odpowiedzi układu przeciwdziałającego zagrożeniom.

Aby przedstawić problem zapewnienia bezpieczeństwa statku powietrznego użytkowanego $\mathrm{w}$ strefie zagrożeń o wysokim poziomie ryzyka, należy 
w pierwszej kolejności przyjrzeć się zagrożeniom, a następnie określić możliwe warianty przeciwdziałania tym zagrożeniom.

Podstawowe elementy, zwiększające bezpieczeństwo i odporność statku powietrznego w czasie wykonywania operacji lotniczych, są zgrupowane w trzech zasadniczych kategoriach: 1) unikanie wykrycia, 2) unikanie trafienia, 3) przetrwanie po trafieniu.

\section{Systemy bezpieczeństwa współczesnych statków powietrznych}

Kluczowe znaczenie dla bezpieczeństwa załogi statku powietrznego w trakcie wykonywania zadania odgrywa obrona indywidualna statku powietrznego. Ochrona indywidualna samolotu sprowadza się głównie do wykrywania promieniowania emitowanego przez radary (pokładowe lub przeciwlotniczych zestawów rakietowych i artyleryjskich) oraz przez laserowe systemy celownicze. Ważnym elementem ochrony jest wykrywanie i identyfikowanie odpalonych pocisków rakietowych, a także wypracowywanie skutecznego przeciwdziałania, np. w postaci użycia aktywnych lub pasywnych urządzeń zakłócających oraz stosowanie manewrów obronnych. Pokładowy system walki radioelektronicznej stanowią urządzenia związane bezpośrednio z osłoną radioelektroniczną statków powietrznych, umożliwiające względnie bezpieczne wykonywanie zadań bojowych. Wyróżnia się przy tym następujące rodzaje urządzeń:

a) odbiorniki ostrzegawczo-rozpoznawcze, w tej kategorii wyróżnia się:

- urządzenia ostrzegające o opromieniowaniu radarem RWR (Radar Warning Receiver);

- urządzenia ostrzegające o opromieniowaniu laserem LWR (Laser Warning Receiver);

- oraz urządzenia ostrzegające przed odpaleniem pocisków rakietowych MWS (Missile Warning System);

b) stacje aktywnych zakłóceń radioelektronicznych (Radar Jamming);

c) stacje zakłócające i urządzenia mylące pracujące w podczerwieni:

- IRCM (Infrared Countermeasures)- pracujące dookólnie;

- DIRCM (Directed IRCM)- pracujące kierunkowo;

d) urządzenia aktywnych zakłóceń w podczerwieni : Towed Decoy (holowane pułapki-wabiki);

e) pasywne systemy zakłóceń w podczerwieni (flary) oraz w zakresach pracy systemów radiolokacyjnych (chaff - dipole).

\subsection{Zagrożenia dla statków powietrznych}

Jednak w ślad za konstrukcjami systemów przeciwdziałania podążają producenci uzbrojenia lotniczego. Dostępne na światowym rynku broni środki optoelektroniczne (telewizyjne, laserowe, termowizyjne 
i kombinowane) często posiadają parametry operacyjne zbliżone do stacji radiolokacyjnych bliskiego zasięgu. Dotychczas głównym źródłem sygnału dla głowicy pocisku były ślady termalne pozostawione przez gazy wylotowe oraz części składowe silnika (wyróżnialne w widmie cieplnym). Obecnie nawet urządzenia rozpraszające ślad termalny (poprzez schładzanie gazów wylotowych) są wyróżnialne. Ponadto tragiczne wydarzenia 11 września w Stanach Zjednoczonych udowodniły, że nie tylko samoloty wojskowe wymagają szczególnego zabezpieczenia. Analizując występujące zagrożenia dla bezpieczeństwa ruchu lotniczego, zarówno wojskowego jak i cywilnego należy na pierwszym miejscu wymienić ręczne zestawy przeciwlotnicze klasy MANPADS. Według danych pochodzących z raportów agencji rządowych Stanów Zjednoczonych (Centralnej Agencji Wywiadowczej, Departamentu Stanu) od 1970 roku zanotowano na świecie przynajmniej 29 przypadków ataków na statki powietrzne cywilnej komunikacji lotniczej z użyciem przenośnych MANPAD. Zestrzelono 30 samolotów, w wyniku czego śmierć poniosło ponad 700 pasażerów. Stwierdzono, że w rękach terrorystów znajduje się bliżej nieokreślona liczba zestawów MANPADS z ogólnej liczby wyprodukowanych na świecie ponad 700 tys. egzemplarzy. Obecnie pociski rakietowe otrzymały wysokiej jakości skanery termiczne, które analizując widmo, porównując dane uzyskane $\mathrm{z}$ pomiaru $\mathrm{z}$ danymi $\mathrm{w}$ bazie danych, potrafią bez przeszkód omijać pułapki cieplne. Dodatkowo najnowsze systemy rakietowe otrzymały zdolność widzenia więcej niż jednego zakresu widma. Poza analizą widma $\mathrm{w}$ podczerwieni, głowica pocisku dokonuje analizy widma w tzw. bliskim ultrafiolecie NUV. Światło w zakresie bliskiego ultrafioletu doskonale się rozprasza $\mathrm{w}$ atmosferze. W przypadku gdy pojawi się $\mathrm{w}$ niej obiekt stały (samolot, śmigłowiec), następuje silna absorpcja tego typu promieniowania przez obiekt i wówczas staję się on doskonale widoczny (ciemna plama) przy wykorzystaniu głowicy NUV.

\subsection{Techniki wykrywania zagrożeń}

Panuje pełna zgoda wszystkich użytkowników przestrzeni powietrznej, że jedynym skutecznym sposobem przeciwdziałania zagrożeniu ze strony MANPADS jest instalacja na płatowcu samolotu czujników ostrzegających o odpaleniu pocisku rakietowego (klasy Missile Warning System - MWS) oraz obrotowych głowic laserowych zapewniających kierunkowe oddziaływanie na sensor podczerwieni znajdujący się w głowicy wystrzelonego pocisku. Urządzenie ostrzegające o wystrzeleniu pocisku MWS ma za zadanie wykryć i określić rodzaj zagrożenia (typ pocisku rakietowego). Detekcja widma cieplnego powstającego w obszarze pracy 
silnika rakietowego pocisku, jego klasyfikacja w oparciu o dane zawarte $\mathrm{w}$ bibliotece danych oraz określenie odległości, kierunku i prędkości zbliżania, pozwala na alarmowanie załogi statku powietrznego o grożącym zagrożeniu $\mathrm{z}$ jednoczesną jego identyfikacją. Znajdujący się na pokładzie system zarządzania osłoną własną (self protection), powinien dokonać automatycznej klasyfikacji zagrożeń oraz przedstawić sposób zwalczenia zagrożeń (w sposób automatyczny bądź manualny). System MWS może być oparty na technice pasywnego wykrywania (głowica optyczna) bądź aktywnego wykrywania (tzw. „cichy” radar). Zaletą systemu pasywnego wykrywania jest lepszy czas wykrycia (dłuższy okres pomiędzy detekcją zagrożenia a uderzeniem pocisku). System ten daje informacje o wystąpieniu zagrożenia już w chwili odpalenia pocisku $\mathrm{z}$ belki wrogiego samolotu. Wadą jest brak możliwości detekcji, w przypadku gdy temperatura spalania paliwa $\mathrm{w}$ silniku rakiety jest $\mathrm{z}$ poza zakresu pracy detektora. W przypadku zastosowania techniki aktywnego wykrywania, zaletą jest możliwość detekcji dowolnego punktu trajektorii ruchu rakiety. Dokonuje się tego poprzez pomiar skutecznej powierzchni odbicia RCS (Radar Cross Section) pocisku. Kolejną zaletą jest możliwość zliczania czasu pozostałego do uderzenia pocisku, co pozwala na właściwe wykorzystanie środków ochrony własnej (np. pułapek termicznych). Wadą systemu aktywnego wykrywania MWS jest przede wszystkim krótki czas ostrzegania, ponadto pocisk może się znajdować w tzw. bramce prędkości (velocity gate), co uniemożliwia detekcję lotu pocisku. Również stosowanie techniki „stealth” (redukcja RCS) znacznie osłabia zdolność detekcji odbiornika. Zdolność do wcześniejszego wykrycia w kombinacji $\mathrm{z}$ poprawioną zdolnością kątowego śledzenia w ultrafiolecie $\mathrm{i}$ w podczerwieni daje możliwość systemowi osłony własnej skuteczne użycie urządzeń klasy DIRCM, co wraz z wykonaniem odpowiedniego manewru statkiem powietrznym powinno zapewnić wystarczająco skuteczna ochronę.

Urządzenia ostrzegające o opromieniowaniu (Radar Warning System RWR) to zasadniczy element osłony radioelektronicznej samolotu. Obecnie wykorzystywana jest trzecia generacja odbiorników - odbiorniki cyfrowe (wykorzystujące np. procesory RISC), które muszą sprostać coraz bardziej wyrafinowanym technikom namierzania. $Z$ uwagi na zastosowanie radarów o coraz większym spektrum przeszukiwania, konieczne jest zapewnienie detekcji pasma częstotliwości $0,5 \div 40 \mathrm{GHz}$, potencjalnie nawet $0,1 \div 94 \mathrm{GHz}$. $\mathrm{Z}$ uwagi na to, że radary impulsowo-dopplerowskie PD używają ciagów impulsów o stałej częstotliwości, to wystarczającą dokładność można byłoby uzyskać nawet przy rozdzielczości $10 \mathrm{MHz}$. Jednak w zakładanych scenariuszach uwzględnia się możliwość operowania kilku bądź kilkunastu 
radarów PD i wówczas okazuje się, że przesunięcia między impulsowe w badanym widmie sygnału mogą być nieznaczne. Stąd założenie, że dwa impulsy nie występują na częstotliwościach bliższych sobie niż $10 \mathrm{MHz}$ nie jest wtedy prawdziwe. Pożądane jest uzyskanie częstotliwości próbkowania rzędu $1 \mathrm{MHz}$. Od częstotliwości pasma $\mathrm{K}(20 \div 40 \mathrm{GHz})$ i wyżej taka rozdzielczość byłaby przydatna tylko dla krótkiego zasięgu wykrycia, natomiast rozszerzenie tej możliwości powyżej $40 \mathrm{GHz}$ byłoby przydatne tylko w stosunku do głowic pocisków naprowadzanych aktywnie na cel. Identyczne rozumowanie przyjmowane jest przy detekcji sygnału o charakterze fali ciagłej. Za pomocą analizy częstotliwościowej RWR może dokonywać filtracji częstotliwościowej, identyfikacji zagrożeń i uszeregowania zagrożeń. Do skutecznego zakłócania radaru pracującego na fali ciagłej, szerokość pasma sygnału zakłócającego musi być bardzo mała, stąd zakres pomiaru przerw między impulsowych powinien wynosić od 25 tysięcy $\mu$ s do $0,5 \mu \mathrm{s}$. Teoretycznie jest wiec możliwość namiaru urządzenia znajdującego się w odległości nawet $3750 \mathrm{~km}$. Pomiar amplitudy umożliwia pomiar odległości do źródła promieniowania. Określenie zasięgu za pomocą analizy poziomu amplitudy jest metodą zgrubnej estymacji (często obarczonej błędem 50\%). Wynika to z faktu, że moc nadajnika może być regulowana. Ważna jest jednak zdolność odbiornika RWR do wyróżniania różnicy poziomu amplitudy sygnału źródła celem zastosowania właściwej dawki sygnału interferencyjnego. Dokładność namiaru kątowego powinna być rzędu $1^{\circ}$ (wartość średnia), jednak przy wykonywaniu złożonych manewrów przez samolot, dopuszczalny jest spadek dokładności nawet do $10^{\circ}$. Kątowy zakres obserwacji powinien wynosić w azymucie $360^{\circ}$, w elewacji $\pm 60^{\circ}$ (pożądany jest szerszy zakres celem minimalizacji oddziaływania manewrów samolotu na zdolności odbiorcze urządzenia). Zakładana pojemność biblioteki danych powinna wynosić co najmniej 1500 rodzajów nadajników (źródeł promieniowania). Innym typem urządzenia, w podobnym stopniu co RWR, odpowiadającym za bezpieczeństwo statku powietrznego jest detektor promieniowania laserowego (Laser Warning Receiver - LWR), przeznaczony do wykrycia, obróbki i zobrazowania zagrożeń związanych $\mathrm{z}$ oświetleniem statku powietrznego przez wrogi system laserowy, dalmierz bądź laserowy podświetlacz celu. Zakres pracy urządzenia musi zapewnić wystarczająco szybką reakcję na zagrożenie, rozumianą jako szybkość podjęcia decyzji o użyciu środków obrony własnej.

\subsection{Techniki przeciwdzialania zagrożeniom.}

W zależności od jakości procesu detekcji zagrożenia dostępny jest określony poziom reakcji układu, im lepiej jest zidentyfikowane zagrożenie, tym skuteczniejsze może być przeciwdziałanie. Środki 
przeciwdziałania (urządzenia zakłócające) dzielą się generalnie na następujące grupy:

- pokładowe środki zakłócające systemy radiolokacyjne OBRCM (Onboard Radar Countermeasure);

- pokładowe podsystemy środków zakłócających urządzenia pracujące w podczerwieni OBIRCM (On-board Infrared Countermeasure subsystem);

- pozapokładowe środki zakłócające systemy radiolokacyjne OBCM (Outboard Radar Countermeasure);

- pozapokładowe środki zakłóceń systemów pracujących w podczerwieni OBIRCM (Out-board Infrared Countermeasures );

- podsystemy przeciwdziałania urządzeniom laserowym LCMS (Laser Countermeasures sub-system).

Zakłócenia aktywne OBRCM realizowane są poprzez wysyłanie sygnałów zakłócających na częstotliwościach pracującej SRL. Najprostszym typem zakłóceń aktywnych są zakłócenia typu szumowego. Na określonych częstotliwościach lub w ich pasmach wytwarza się jednostajne szumy, które blokują pewien zakres częstotliwości, uniemożliwiając jego wykorzystanie. Tego typu zakłócenia realizować mogą skutecznie jedynie duże, ciężkie nadajniki, a więc mogą być przenoszone tylko przez odpowiednio duże samoloty. Najskuteczniejszym typem zakłóceń aktywnych są tzw. zakłócenia mylące, wykorzystujące technikę retranslacji sygnałów. Skutkiem takiego działania jest wytworzenie fałszywego echa obiektu, fałszywego wskazania układu pomiaru odległości, azymutu i wysokości celu, a tym samym zerwania śledzenia obiektu. Znając typ radaru, dysponując jego charakterystyką $\mathrm{w}$ bibliotece danych systemu, można bez problemu wyemitować, w trakcie opromieniowania listkiem bocznym, sygnał o odpowiednio dopasowanym poziomie amplitudy. Sygnał odebrany z kierunku listka bocznego potraktowany zostaje przez dyskryminator amplitudowy radaru jako cel rzeczywisty i zobrazowany na wskaźniku na kierunku, na którym go w rzeczywistości nie ma. Moc sygnału nadawanego dla większości aplikacji powinna być rzędu $1 \mathrm{~kW}$, jednak wartość ta powinna być regulowana tak, aby promieniowany sygnał był bezpośrednio związany z RCS (powierzchnią skuteczną odbicia). Tego typu urządzenia muszą być zdolne do stosowania programów zakłóceń przeciwko radarom impulsowym, impulsowo-dopplerowskim i radarom pracującym na fali ciagłej.

Cele (wabiki) holowane (Towed Decoy) pokrywaja pasmo częstotliwości $4,5 \div 18 \mathrm{GHz}$. Sterowanie systemu realizowane jest przy wykorzystaniu światłowodu, będącego integralną częścią liny (o długości $50 \div 150 \mathrm{~m}$ ), 
łączącej go z samolotem po odstrzeleniu. Zadaniem tej pułapki jest wytworzenie sygnału zwrotnego (sygnału imitującego odbicie radarowe) o odpowiednio dużej amplitudzie, tak aby skupić uwagę środków ogniowych przeciwnika naprowadzanych radiolokacyjnie. Tego typu wabik jest bardzo trudny do zlokalizowania i wyróżnienia na tle rzeczywistego celu. Porusza się on z prędkością, wysokością i kierunkiem rzeczywistego celu, stąd algorytmy wyróżniania celów rzeczywistych na tle zakłóceń (celów pozornych) oparte na śledzeniu w prędkości, położeniu kątowym stają się nieskuteczne. Głowica pocisku rakietowego zaatakuje cel o większym kontraście radiolokacyjnym, czyli wabik. W opinii specjalistów amerykańskich, właśnie holowane wabiki radiolokacyjne sa najskuteczniejszym sposobem ochrony własnej lotnictwa uderzeniowego. Wyprzedzają one swoimi możliwościami wszystkie inne systemy obrony pasywnej (dipole radiolokacyjne). Ostatnim typem w tej klasie zakłóceń są dipole radiolokacyjne, wystrzeliwane z pokładowych wyrzutni na podobnej zasadzie jak flary termiczne. U podstaw tego rozwiązania leży teoria anteny dipolowej, której wyjściowy port jest zwarty. Stwierdzono, że największe możliwości refleksyjne fal elektromagnetycznych występują przy zastosowaniu dipoli o długości $0,46 \div 0,48$ długości fali. $Z$ kolei liczba elementarnych dipoli r-lok jest kombinacją matematyczną, która ma zapewnić powstanie obłoku radiolokacyjnego (o określonej RCS) $\mathrm{w}$ przestrzeni otaczającej osłaniany statek powietrzny. Chmura taka najskuteczniej absorbuje promieniowanie elektromagnetyczne w zadanym paśmie częstotliwości, jeśli odległości pomiędzy dipolami są wielokrotnością dwóch długości fali.

Dla zapewnienia osłony radioelektronicznej obiektu należy zastosować ładunki zawierające dipole o różnych długościach, tak aby pokryły one całe pasmo częstotliwości $0,5 \div 18 \mathrm{GHz}$. Tego typu osłona jest niestety nieskuteczna w stosunku do radarów impulsowo-dopplerowskich, w których mierzona jest różnica częstotliwości, jaka występuje pomiędzy sygnałem wysyłanym, a odbitym od poruszającego się celu. Paski metalizowanej folii bądź metalizowane włókna szklane poruszają się jedynie $\mathrm{z}$ wiatrem, stale opadając na ziemię. Wystarczy, wykorzystując efekt Dopplera, odfiltrować sygnały, przy których ta różnica częstotliwości powstaje i z ekranu radiolokatora znikają cele pozorne tworzone przez dipole. Pokładowe podsystemy IRCM (Infrared Countermeasure), to urządzenia zakłócające, które emitują modulowaną energię (promieniowanie elektromagnetyczne modulowane kodem impulsowym) w wybranym zakresie podczerwieni. Ta modulowana energia (impulsy świetlne) powodują błędy w sekcji kierowania i sterowania $\mathrm{i} \mathrm{w}$ rezultacie przecelowanie przez głowicę pocisku naprowadzanego na podczerwień. 
Flary termiczne pozostają najprostszym i najtańszym sposobem zakłócania w podczerwieni. Użycie ich na współczesnym polu walki staje się coraz bardziej nieefektywne, co doświadczyło w szczególności lotnictwo byłego ZSRR w czasie wojny w Afganistanie. Podstawowym zadaniem flary jest wytworzenie źródła promieniowania cieplnego o energii wyższej od osłanianego obiektu. Najbardziej rozpowszechnione są w dalszym ciagu flary pirotechniczne. Aktualnie stosowane flary odpalone ze statku powietrznego zapewniają energię niemal zaraz po odstrzale współmierną do promieniowania silnika i w miarę zmniejszania prędkości (opadania), energia ta zwiększa się 3 lub 4-krotnie. Skuteczność stosowania osłony w postaci obłoku promieniowania cieplnego zależy od współpracy systemu odpalającego flary z systemami wykrywania zagrożeń. Podstawowym problemem jest wybór odpowiedniego momentu odpalenia flar (bardzo krótki czas spalania), liczby flar i sekwencji odpaleń. Pilot statku powietrznego może tylko $\mathrm{w}$ przypadkowy sposób, wykonując zadany manewr zgodnie z taktyką walki powietrznej, trafić we właściwy moment odpalenia flar. Ważnym wymaganiem w odniesieniu do flary jest jej czas inicjacji (spalania) po wystrzeleniu. Istotnym jest, aby moment ten został zainicjowany przed jej wejściem w pole widzenia głowicy pocisku. Problemem w rozwiązaniach klasycznych pozostaje fakt szybkiego opadania flary. Zakłada się, że w nowych rozwiązaniach, flary będą podążać za osłanianym obiektem, co podniesie efektywność ich użycia jak również, sygnatura ich rozbłysku będzie dostosowana do sygnatury cieplnej osłanianego obiektu.

Podstawowym zadaniem podsystemu LCMS (Laser Countermeasures Subsystem) jest zwiększanie błędów namiaru odległości (błędy przecelowania) przez głowice wrogiego pocisku rakietowego, co ma spowodować rozerwanie pocisku w bezpiecznej odległości. Detekcja i identyfikacja zagrożeń związanych z wykorzystaniem techniki laserowej jest realizowana przez urządzenie LWR w połączeniu z innymi czujnikami ostrzegawczymi. Największe trudności powstają przy przeciwdziałaniu dalmierzom laserowym (Range Finders), ponieważ wykorzystują one technikę bardzo krótkich impulsów podświetlających oraz ekstremalnie małych przerw między impulsowych. Najskuteczniejszym sposobem zwalczania tego typu zagrożeń jest emisja serii impulsów o odpowiednim poziomie amplitudy w kierunku głowicy dalmierza, celem zaimitowania obecności co najmniej kilku celów na większych odległościach. Nowoczesne systemy mają zdolność przesyłania sygnałów na odległość 150 mil morskich.

\section{Podsumowanie}

Efektywność zastosowanego algorytmu (software) użycia środków przeciwdziałania oceniana jest $\mathrm{w}$ warunkach laboratoriów walki 
elektronicznej EW (modelowanie) oraz na poligonach wojskowych. Funkcję oceny efektywności systemu przeciwdziałania (hardware) określa się w zależności od przyjętego programu zadania na etapie planowania misji (mission planning) oraz przewidywanych zagrożeń elektromagnetycznych (scenariuszy EW). Programy zawierające algorytmy działania urządzeń służących do osłony statków powietrznych są tworzone indywidualnie w każdym z państw NATO i podobnie jak Narodowa Baza Danych Emiterów strzeżone są tajemnicą państwową. Aktualnie NATO nie dysponuje odpowiednimi zdolnościami do zapewnienia ochrony cywilnym statkom powietrznym. Natomiast w pracach zespołów technicznych NATO, podejmujących tematykę ochrony wojskowych samolotów szerokokadłubowych są poruszane aspekty, które mogą zainteresować właścicieli cywilnych linii lotniczych. Wykonywane prace studyjne oraz prowadzone próby, pozwalają na zademonstrowanie efektywności zastosowanych nowych technologii w zakresie przeciwdziałania systemom naprowadzanym na podczerwień. Aktualne przepisy regulujące funkcjonowanie lotnictwa cywilnego $\mathrm{w}$ warunkach pokoju zabraniaja wykorzystywanie flar w trakcie operowania na lotniskach cywilnych i w ich okolicach. Przepisy te obowiązują nawet $\mathrm{w}$ warunkach występowania bezpośredniego zagrożenia ze strony bojówek terrorystycznych, także w warunkach kryzysu. Stąd alternatywnym sposobem osłony lotnictwa cywilnego jest utworzenie tzw. parasola mikrofalowego w strefie wokół lotniska, czyli tam gdzie jest największe zagrożenie ze strony systemów MANPADS. Nowym zagrożeniem, które zyskało na znaczeniu w ostatnich latach (operacja koalicji antyterrorystycznej w Iraku), jest konieczność zapewnienia bezpieczeństwa śmigłowcom w trakcie realizacji zadań. Liczba utraconych śmigłowców przez siły amerykańskie od uderzenia pocisków z granatników przeciwpancernych, przyczyniła się do zdefiniowania nowej potrzeby operacyjnej. Zadanie to wytycza nowy kierunek w temacie dotyczącym zwiększenia bezpieczeństwa wykonywania lotów nad wrogim terytorium.

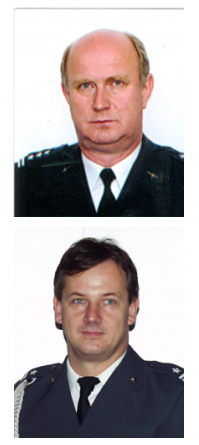

Ph.D., Eng., Loroch Leszek, AFIT, R\&D coordinator of aeronautical projects. Specialist in the field of aircraft armament. Experienced in designing, testing, and implementation of modernized on-board aircraft armament and air combat assets. Former member of the commission for aircraft accidents investigation. A lot of publications in the field.

Mariusz Masiewicz: Head of Laboratory for integrated airborne systems division for Avionics, he for 17 years deals with projects on avionics operational use. 